\title{
Article
}

\section{Cycling along a River: New Access, New Values?}

\author{
Matthieu Adam ${ }^{1, *} \mathbb{}$, Marylise Cottet ${ }^{1}\left(\mathbb{D}\right.$, Sylvie Morardet ${ }^{2}$, Lise Vaudor ${ }^{1}$, Laure Coussout ${ }^{2}$ and \\ Anne Rivière-Honegger ${ }^{1}$ \\ 1 Université de Lyon, CNRS, UMR 5600 EVS, ENS de Lyon, F-69007 Lyon, France; \\ marylise.cottet@ens-lyon.fr (M.C.); lise.vaudor@ens-lyon.fr (L.V.); anne.honegger@ens-lyon.fr (A.R.-H.) \\ 2 G-EAU, AgroParisTech, CIRAD, IRD, INRAE, Montpellier SupAgro, Université Montpellier, \\ 34196 Montpellier, France; sylvie.morardet@inrae.fr (S.M.); laure.coussout@free.fr (L.C.) \\ * Correspondence: matthieu.adam@ens-lyon.fr
}

Received: 14 September 2020; Accepted: 6 November 2020; Published: 10 November 2020

\begin{abstract}
The ViaRhôna is an $815 \mathrm{~km}$ cycle route running along the Rhône River from Lake Geneva to the Mediterranean Sea. We examine the influence of this type of cycle route on the relationship between route users (including the local population, itinerant cyclists and foreign tourists) and the river landscapes. This relationship is approached from the angle of the use of the riverbanks as well as the perceived image, the value, and the knowledge associated with the river and its landscapes. Our survey based on interviews $(n=16)$ and questionnaires $(n=546)$ produced the following results. The features of the cycle route and the related activities that it makes possible drain a special segment of the population that, in spite of its diverse sociological composition, shares similar tastes. The creation of the cycle route has led to an increase in use of the riverbanks both by tourists and local people. The experience that it offers contributes to enhancing the value that users place on the river. This is due to a change in the image of the river following the (re)discovery of its natural environments. On the other hand, knowledge of one's natural environments is not modified. These results raise the question of possible changes in the degree to which users support policies targeting the preservation and restoration of the river.
\end{abstract}

Keywords: cycling; Rhône River; knowledge; values; tourism; landscape; nature-society

\section{Introduction}

The relationships between societies and rivers have been widely studied. The results show that they have changed over time. Starting in the middle of the 1800s, a disconnection between societies and rivers occurred due to the problems they caused (flooding, pollution, etc.) and to the work done on rivers to protect against those problems or to make use of rivers. This weakening of relationships is physical in nature (lack of access to riverbanks) as well as cognitive (less knowledge of the river and its landscapes) and emotional (lesser value attributed). This situation is reinforced by the fact that development work on rivers often results in more artificial landscapes and it has long been known that this negatively impacts the value attributed to rivers [1]. This decrease in the value attributed is not without consequences, notably given the current importance of environmental preservation. The value placed on rivers strongly contributes to public support for policies to preserve environments and landscapes [2,3]. It is with the above in mind that current public development policies encourage stronger bonds with rivers. This is illustrated, for example, by efforts made starting in the 1960s in North America to restore waterfronts [4-6]. More recently, it has been the case in rural areas where rivers are seen as the backbone of local development projects [7]. These public policies, now firmly established, better integrate the many components, the objective being to create bonds between people and the river as well as to integrate the culture, economy, and environment of societies and pay greater attention to the landscapes making up their area. 
Cycle routes, a common form of recreational infrastructure, are now widely used by local governments to enhance the attractiveness of their area for tourists. That is the case for cities (Roman and Roman, 2014), but even more so for large territories where cycle routes go through multiple local governments and even entire countries. Routes such as the Route verte in Canada [8], the North Sea Cycle Route from Scotland to Norway [9], the Danube Cycle [10], and the Loire à vélo route in France [11] are now common and growing in number. The last two routes are also part of the EuroVelo 6 route, an itinerary spanning Europe and linking the Atlantic to the Black Sea along numerous rivers. For now, research on large cycle routes is relatively sparse if compared to other fields in tourism or to the study on links between territories and daily mobility. Among the existing studies, most have focused on analysing the quality of projects in view of improvements [12] or on measuring the use of infrastructures in an essentially economic approach [13]. A second category of study focusses on identification of users [9]. This latter category of study has revealed that the users of these routes are mainly, according to the EuroVelo classification system, day trippers (who cycle for a day or for just a few hours), sports cyclists (for whom cycling is essentially a sports activity), and itinerant cyclists (who cycle a number of successive days in a journey and lodge along the way). The percentage of users for practical purposes (travel to work, to the grocery store, etc.) is small. Furthermore, users come primarily from areas close to the routes. Other research has investigated the activities of cyclists, their experiences on the routes [14], and their needs [15]. Once again, the approach deals essentially with the economic and development aspects, and exclusively addresses the itinerant cyclists, not all users, contrary to the study presented in this article.

Most of the work on cycle routes neglects the issues concerning the links with the surrounding landscapes. That is, however, precisely the heart of this case study on the ViaRhôna, an $815 \mathrm{~km}$ cycle route that follows the entire French part of the Rhône River from the Swiss border to the Mediterranean Sea. We examine the influence of this type of cycle route on the relationships that route users-including the local population, itinerant cyclists, and foreign tourists—create and maintain, through their practices, with the river landscapes. Inspired by the social practice theory [16], we consider that the practices (here cycling and other active mobility) arise from the meeting of "skills", "materials", and "meanings" [17]. For the social practice theory, materiality is both that of the object at the heart of the practice, here the bicycle as a vehicle (its comfort, its speed, the posture it imposes), that of the immediate space, here the cycle route (its coating, its layout), and that of the visual environment of the practice, here the Rhone river and its landscapes. "Meanings" encompass mental images, values, and the way they are formed by individuals, i.e., by sensorial perceptions. The landscape is therefore a key element of cycling and other active mobility practices, notably through the materiality it embodies and the meanings it represents [18]. This is why we are mainly interested, in this article, in the relationship between route users and landscapes of the Rhone (it does not deal with "skills", nor with the "materials" of the bicycle and of the cycle route). This relationship is approached according to four main dimensions: By the use of the riverbanks and the activities carried out there, by the sensory perceptions of the Rhone River landscapes and the images mentally associated to them, by the values attached to them and finally by the knowledge linked to them. The objective of this article is to understand the extent to which the creation of a bicycle route affects the relationship between users and the river landscapes in these four dimensions. Has the creation of the ViaRhôna enabled users to return to or increase their use of the riverbanks? Has the increased familiarity with the river contributed to modifying perceived images of the river, to increasing knowledge, and the values attributed to it? Is it possible to say that by providing new access to the river, the ViaRhôna has resulted in greater value for the river and its landscapes? 


\section{Materials and Methods}

\subsection{Study Site}

Our study focuses on the French part of the Rhône River, one of the main Mediterranean rivers, which originates at the Furka Glacier in the Swiss Alps and flows into the Mediterranean Sea. The river is $812 \mathrm{~km}$ long, with more than $500 \mathrm{~km}$ located in France. The history of the river and its relationship with the riverside populations conform to the "classic" model mentioned above. Major development work was undertaken in a first step (1860-1930s) to develop navigation and protect inhabitants and infrastructure against floods and, in a second step (1950-1990s), to favour economic development, especially energy production. These large engineering projects significantly modified the landscapes (e.g., homogenisation of habitats, "artificialisation" of its banks). These changes, combined with the evolution of lifestyles, contributed to modifying the relationship between the river and the local residents. Over time, a reduction in the types of activities, and the time spent along the river were observed and people attributed less value to surrounding landscapes [19]. Even up to the late 1990s, the development of recreational activities was seen as competing with preservation issues for Rhône ecosystems and landscapes [20]. The emergence of environmental concerns on the international level, in conjunction with a local crisis (a highly destructive flood in 2003), incited the local and regional stakeholders to implement a more sustainable development project for the Rhône River. This intent took the form of two successive action plans called the Rhône Plan (2007-2013 and 2015-2020). In this plan, the objective is to make the river"a link between inhabitants and their territory". One of the most emblematic projects is the ViaRhôna, a cycle route along the river linking Lake Geneva, in Switzerland, with the Mediterranean Sea. The route serves as a link between rural and urban areas (Geneva, Lyon, Valence, Avignon, etc.) and crosses through diverse landscapes that are highly anthropized. They result from the mix between the natural dynamics of the river and the uses made of it by humans (navigation, irrigation, hydropower, industrial uses, etc.) [21]. Some sectors may be perceived as "natural" whereas others are highly impacted by human activities (highly visible canal, urban and industrial sites, etc.). This diversity of landscapes was taken into account in selecting the three study sectors (see Figure 1), among other factors (age of the cycle-route infrastructure, type of contracting authority) (see Table 1).

Table 1. Main landscape features of the study sites.

\begin{tabular}{|c|c|c|c|}
\hline & $\begin{array}{l}\text { Upstream: Belley to Groslée, } \\
\text { via Saint-Genix-sur-Guiers }\end{array}$ & $\begin{array}{l}\text { Midsection: Vienne to } \\
\text { Sablons, via Condrieu }\end{array}$ & $\begin{array}{l}\text { Downstream: Rochemaure } \\
\text { to Bourg-Saint-Andéol }\end{array}$ \\
\hline $\begin{array}{l}\text { Link between } \\
\text { the ViaRhôna and } \\
\text { the river }\end{array}$ & $\begin{array}{l}\text { Constant proximity to } \\
\text { the Rhône (alternating } \\
\text { between the old Rhône and } \\
\text { the channelised Rhône), with } \\
\text { the exception of a few detours } \\
\text { on country roads or behind } \\
\text { the dike. }\end{array}$ & $\begin{array}{l}\text { Occasionally directly } \\
\text { on the bank } \\
\text { of the channelised Rhône, } \\
\text { but most often behind } \\
\text { the dike (rather monotonous } \\
\text { in the southern section). A } \\
\text { few sections farther from } \\
\text { the river (vegetable farms, } \\
\text { wooded areas). }\end{array}$ & $\begin{array}{l}\text { One half along the Rhône } \\
\text { bypass canal, then directly } \\
\text { along the river. A few } \\
\text { sections on more distant } \\
\text { country roads or on paths } \\
\text { through wooded areas. }\end{array}$ \\
\hline Main landscape features & $\begin{array}{l}\text { Natural landscapes: cliffs, } \\
\text { wooded areas, wetlands. } \\
\text { Farming landscapes: } \\
\text { vegetable farms and orchards. } \\
\text { Landscapes blocked by far-off } \\
\text { mountains (Alps and Jura). }\end{array}$ & $\begin{array}{l}\text { Farming landscapes: } \\
\text { orchards, vegetable farms } \\
\text { and terraced vineyards. } \\
\text { Industrial landscapes. } \\
\text { Open, hilly landscapes. }\end{array}$ & $\begin{array}{l}\text { Natural landscapes: wooded } \\
\text { areas and cliffs. } \\
\text { Industrial landscapes in a } \\
\text { few spots. } \\
\text { Farming landscapes. } \\
\text { Open landscapes with cliffs } \\
\text { and hills in a few spots. }\end{array}$ \\
\hline Industrial landscapes & $\begin{array}{l}\text { In some places: quarries, } \\
\text { hydroelectric plants. }\end{array}$ & $\begin{array}{c}\text { In many places: } \\
\text { hydroelectric plants, nuclear } \\
\text { power plants, chemical } \\
\text { factories, warehouses. }\end{array}$ & $\begin{array}{l}\text { In some places: cement } \\
\text { plant, hydroelectric plants. }\end{array}$ \\
\hline Urban landscapes & $\begin{array}{l}\text { No urban landscapes (and few } \\
\text { villages entered). }\end{array}$ & $\begin{array}{l}\text { Mostly urban and } \\
\text { peri-urban landscapes. }\end{array}$ & $\begin{array}{l}\text { Villages perched above } \\
\text { the river in a few spots. }\end{array}$ \\
\hline
\end{tabular}




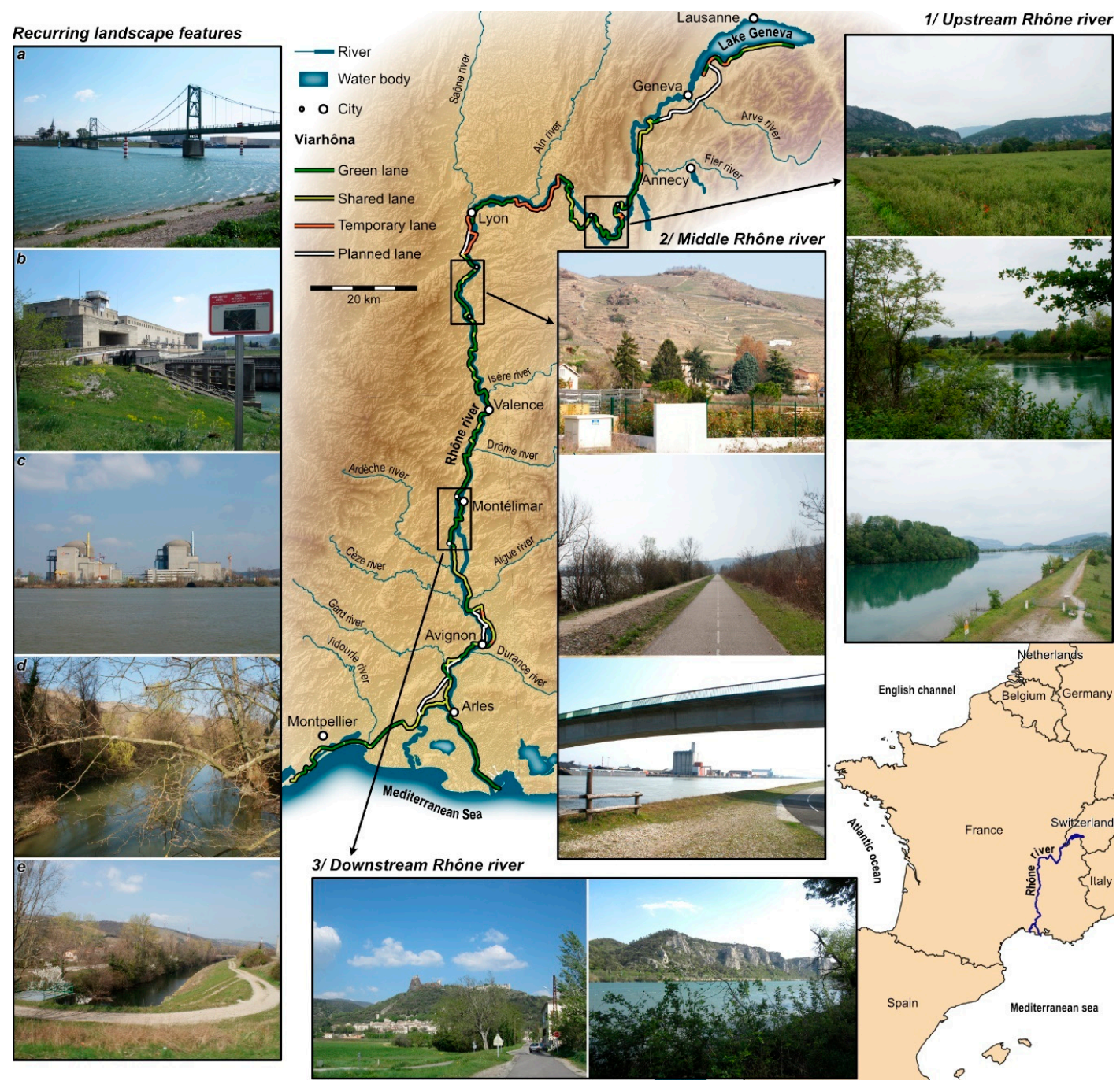

Figure 1. Map showing the position of the three study sites and the corresponding landscapes. The photos in the column on the left show recurring landscape features, namely (a) bridges, (b) hydroelectric plants, (c) industrial sites, (d) former channels, and (e) bypass.

\subsection{Data Collection}

A survey was run on the three river sections. Interviews $(n=16)$ were carried out in the spring of 2017 and a survey using questionnaires $(n=546)$ took place in June and July 2017. The study targeted all users of the ViaRhôna, whether walkers, cyclists, day trippers, sports cyclists, or itinerant cyclists.

\subsubsection{Semi-Structured Interviews}

The semi-structured interviews served the double purpose of guiding the preparation of the questionnaires and providing in-depth knowledge on the uses of the ViaRhôna and perceptions and values of the interviewed persons concerning the Rhône River. The interviews were more specifically interested in qualifying the impact of the ViaRhôna on uses, perceptions, and values. The interviewed persons were selected to ensure a high degree of diversity. This diversity corresponds to the sections used (upstream, midsection, and downstream), activities (means of transport, type of travel, time previously invested in the activity, etc.) and the types of people interviewed (social and professional categories, age, gender, place of residence, etc.). The 16 interviews were carried out face to face, generally in the home of the person interviewed. They lasted between $55 \mathrm{~min}$ and one hour and $40 \mathrm{~min}$. 


\subsubsection{The Questionnaire}

The questionnaire, comprising a majority of closed questions and a few open questions, was structured in four parts.

- The first part looked at the activities of the person (type of travel, sectors visited, frequency of activity, and years of practice). Some questions aimed to characterise the motivations of people to use the ViaRhôna using a psychometric scale inspired by the work of Smith and Moore [22], who used this scale to characterise demand for recreational activities and sites.

- The second part examined the perception of Rhône landscapes by the respondents and their degree of familiarity with them. A photo-questionnaire depicting diverse river landscapes [23] was used. Participants were asked to assess, using a visual scale, the degree to which 16 landscapes were emblematic of the Rhône River. An open question was also asked in order to assess their knowledge on those landscapes (and notably whether they were capable of naming it). Eight categories of landscapes (each represented by two photographs) were selected in as much as they were deemed emblematic of the Rhône by stakeholders in the Rhône Plan. The sectors seen as emblematic by stakeholders were identified using qualitative analysis of interviews carried out with those persons during another part of the research project (their opinions were gathered in a previous phase of the scientific project).

- The third part studied the impact of the cycle route on the relationship of the respondents with the river, in particular in terms of the image of and the values attributed to the river. To characterise those values, we used the typology devised by Brown and Raymond [24].

- The fourth part aimed to characterise the respondent sociologically and based on where the person lived.

Hard copies of the questionnaire were made available in French, English, and German. People were encouraged to reply on the spot along the ViaRhôna. However, for those wishing not to reply immediately, it was possible to send the questionnaire in by mail (a stamped envelope was provided). The collection of data was highly empirical and targeted a maximum of respondents in that virtually every person (walking and cycling) passing in front of the survey tables along the route was stopped. The percentage of people stopped who accepted to respond to the questionnaire exceeded $50 \%$. This high proportion may be explained by the context, a recreational or vacation moment when people are more inclined to "give freely of their time", and by the chance given to take a break in their activity. The return rate by mail was also exceptionally high at $68 \%$ for the upstream and midsection (44 questionnaires out of the 65 distributed) and $63 \%$ for the downstream section (44 out of 70). However, it was not easy to question all the user categories. In general, day trippers and itinerant cyclists willingly accepted to devote some time to the questionnaire, whereas that was less frequently the case for sports cyclists and particularly for "utilitarian" cyclists. Sports cyclists stopped only exceptionally when they were in a group. The "utilitarian" cyclists were frequently in a hurry, either because they had an appointment somewhere or, more often, because they were going to work or were returning home for lunch. Finally, the persons most reluctant to take the time were those travelling with children. For the most reluctant user categories, we often supplied an envelope with the questionnaire in case they would eventually accept to respond.

\subsection{Data Analysis}

The interviews underwent qualitative analysis through content analysis. In other words, they were systematically processed using a multi-criteria analysis system [25]. The questionnaires were statistically analysed. All analyses (univariate descriptions, statistical tests, random forests, graphic creation) were carried out using the R programming and statistical environment (R Core Team, 2018). To test the significance of the link between two variables, we carried out various kinds of tests according to the qualitative or quantitative nature of the response and predictor variables (Chi-squared tests if both variables were qualitative, ANOVAs if one of them was quantitative). If $\mathrm{p}$-values were $\leq 0.01$ we 
rejected the hypothesis that the two variables considered were independent from each other. To model response variables according to a variety of both quantitative and qualitative variables, we used random forests [26]. These consist of a large number of decision trees built on varying, randomly chosen portions of the dataset and are used to model either a quantitative response (regression) or a categorical one (classification). Random forests enabled us to assess the relative importance of descriptors to model the answer to a particular question. To analyse open questions, we performed a statistical analysis of the textual data [27] using the open source software Iramuteq [28]. In particular, to identify the words that were over-represented in the discourse of participants according to their user profile of the ViaRhôna, we measured specificity scores [29]. We considered that a term was specific to a category of respondents if its specificity index was greater than 2 [30].

\section{Results}

\subsection{The Surveyed Population}

The people using the ViaRhôna are highly diverse, particularly during the summer (see Table 2). A total of 546 people responded to the questionnaire (191 upstream, 178 in the midsection, and 177 downstream). Among them, $46.4 \%$ were "tourists", meaning they spent the night prior to the survey in lodging other than their home. A full $77 \%$ of the users questioned were exclusively cyclists and $18 \%$ were exclusively on foot, with approximately $5 \%$ alternating between the two or using other means of travel (in-line skates, electric wheelchair). The day trippers (people there for a day or just a few hours) were the most numerous ( $42 \%$ of respondents), followed by itinerant cyclists ( $34 \%$ ), sports cyclists $(17 \%)$, and "utilitarian" users $(7 \%)$. The geographical origin of respondents was varied, though $75 \%$ were French $(n=406)$. Among the 15 other nationalities represented, the most represented were Switzerland $(n=46)$, Germany $(n=33)$, and the Netherlands $(n=18)$. The respondents living in a town along the Rhône represented $43 \%$ of the total. They were often local people (37\% of respondents who lived less than $20 \mathrm{~km}$ from the survey site) or from adjacent French departments (18\% of respondents). Men represented $57 \%$ of respondents, a proportion that varied depending on the activity. For example, men represented $65 \%$ of the sports cyclists, $55 \%$ of the itinerant cyclists, and $54 \%$ of the utilitarian users. Women represented a majority only among the day trippers $(51 \%)$. The respondents were relatively old (median age 56). The most common socio-professional category was that of retired people $(34.7 \%)$. They were followed by executive personnel and professionals $(22.6 \%)$ and by technicians and equivalent staff $(17.2 \%)$, which together represent $75 \%$ of the respondents among the active population in the sample. School children (mid and high schools) and students represented $8.7 \%$ of the respondents and other people with no professional activity (unemployed and home keepers) $3.6 \%$.

Table 2. Main geographical and sociological criteria of respondents according to their user profile.

\begin{tabular}{cccccc}
\hline & $\begin{array}{c}\text { Itinerant } \\
\text { Cyclists }\end{array}$ & $\begin{array}{c}\text { Day } \\
\text { Trippers }\end{array}$ & $\begin{array}{c}\text { Utilitarian } \\
\text { Users }\end{array}$ & $\begin{array}{c}\text { Sports } \\
\text { Cyclists }\end{array}$ & Total \\
\hline Median age (years) & 46.4 & 56.4 & 42.4 & 51.7 & 51.6 \\
Men (\%) & 55.7 & 54.9 & 57.9 & 70.3 & 57.3 \\
Live along the Rhône (\%) & 14.9 & 63.2 & 60.1 & 58.3 & 44.2 \\
Tourists (\%) & 87.3 & 24.4 & 24.3 & 32.1 & 46.4 \\
Retired (\%) & 20.9 & 45.3 & 22.9 & 40 & 34.7 \\
School children and students (\%) & 10.4 & 5.5 & 14.3 & 11.3 & 8.7 \\
Executive personnel (\%) & 30.7 & 19.4 & 14.3 & 17.5 & 22.6 \\
Technicians and equivalent staff (\%) & 23.3 & 12.9 & 22.9 & 13.8 & 17.2 \\
Labourers (\%) & 1.2 & 1 & 5.1 & 3.8 & 2 \\
Locals (\%) & 5.2 & 54.5 & 57.9 & 52.4 & 37.9 \\
Regionals (\%) & 14.4 & 20.9 & 21.1 & 19.1 & 18.5 \\
French (\%) & 29.3 & 12.3 & 10.5 & 11.9 & 17.9 \\
Foreign (\%) & 51.1 & 10.9 & 10.5 & 16.6 & 25.7 \\
\hline
\end{tabular}

In parallel to our study, a frequentation survey on the ViaRhôna was commissioned by the promoters of the route and carried out from March to November 2017 [31]. On 29 sites, 2708 cyclists 
answered a questionnaire. Our results are consistent with those of the frequentation survey. For example, the results of the frequentation survey indicated that $68.1 \%$ of cyclists are male, $29.6 \%$ of respondents are retired, and the average age is 50 . The differences may be explained by the fact that our survey took place during the summer and outside of urban areas. We recorded a higher percentage of foreigners $(25.7 \%$ vs. $3.9 \%)$ and of tourists $(46.4 \%$ vs. $35.3 \%)$, and a lower percentage of utilitarian cyclists (10\% vs. $13 \%)$. These results hence comforts the validity of our user sample.

\subsection{Survey Results}

It is important to note the consistency of the answers about the motivations to use the ViaRhôna, image of the river, and values attributed to it. The answers (variables) to the questions differ only slightly and are not significantly affected by the study sites, the sociological traits or the place of residence of respondents, nor the type of route use. The variables concerning motivations, the image, and values are, in most cases, statistically independent of the above factors ( $p$-value $>0.1)$. In the following paragraphs, we comment only the statistically significant differences. However, they should not mask the high degree of homogeneity in the responses collected.

\subsubsection{The River Environment and Uses as Sources of Motivation}

A number of questions dealt with the motivations of people to use the ViaRhôna. When asked "What is the primary purpose of your visit to the ViaRhôna today?", the respondents had to choose one or more answers from a list. The three most common answers dealt with the activity itself, namely "do sports" (23.2\%), "go for a walk, fresh air" (20.6\%), "hike/ride" (20\%). The answer "spend time along the Rhône" came in fourth place (14.2\%). It was selected more frequently by itinerant cyclists $(15.7 \%)$ than by sports cyclists $(14 \%)$ and day trippers $(13.5 \%)(p \leq 0.001)$. It was selected least frequently by the utilitarian users $(10.8 \%)$. The desire to discover the river itself is a strong motivation for the itinerant cyclists. Even more remarkable is the fact that over a quarter of the foreign respondents $(26.3 \%)$ answered that their main motivation for using the ViaRhôna was to spend time along the Rhône $(p \leq 0.001)$. That was the case for only $8.3 \%$ of the local people. Also, whereas $18.3 \%$ of people not living along the Rhône indicated that the river was their main motivation, that was the case for only $10 \%$ of people living along the Rhône $(p \leq 0.001)$. The capacity to travel along the river, i.e., to discover the river for most foreigners, is a major factor in attracting foreign tourists. As might be expected, the river itself was a lesser motivation for people who come easily and frequently (even daily) into contact with it and are thus accustomed to seeing it.

In response to the question "For your particular activity, why did you choose the ViaRhôna rather than some other place?", respondents were asked to select three answers (maximum) among the eight provided, that included technical aspects concerning the route as well as its geographic location and landscapes (see Figure 2). The answers most often selected fit into two radically different kinds of motivation, namely the safety and comfort of the route on the one hand (e.g., "The ViaRhôna is a spot that is safe and where I feel safe" (50\%), "The ViaRhôna makes for easy travel (layout, road surface, wind protection) (32.4\%)) and the landscapes travelled through on the other, (e.g., "The ViaRhôna goes through nice areas" (48.5\%), "The ViaRhôna travels along the Rhône River" (36.8\%)).

The psychometric scale used by respondents to assess "to what degree" (0 to 10) a total of 17 reasons incited them to travel to the ViaRhôna filled out the above observations. The reason "to remain in 'contact' with the Rhône" received the fifth best average assessment (5.9), following reasons related to the activity ("for physical exercise" (7.4), "to physically relax" (6.6)) and those related to the site ("to experience nature" (7.2), "for some time away from the city" (6.4)). Similar to the other indicators concerning motivations, the psychometric scale revealed that the desire to spend time along the Rhône is an important motivation, stronger than the collective reasons ("for a family activity", "to spend time with friends or 'my group'", "to meet new people", etc.) and the personal reasons ("to take a step back and think about life", "to express my creativity by drawing, taking photos", "to show other people that I can do it", etc.). Random-forest calculations showed that the assessment of "to remain in 'contact' 
with the Rhône" was influenced primarily by two other motivations, namely "to experience nature" and "to learn about nature". The fourth variable among those most predictive of the importance attributed to the Rhône in the set of reasons inciting people to use the ViaRhôna was the perceived value of the Rhône. Consequently, people motivated by the river tend to attribute value to it.

\section{For your particular activity, why did you choose the ViaRhôna rather than some other place? (Three answers maximum)}

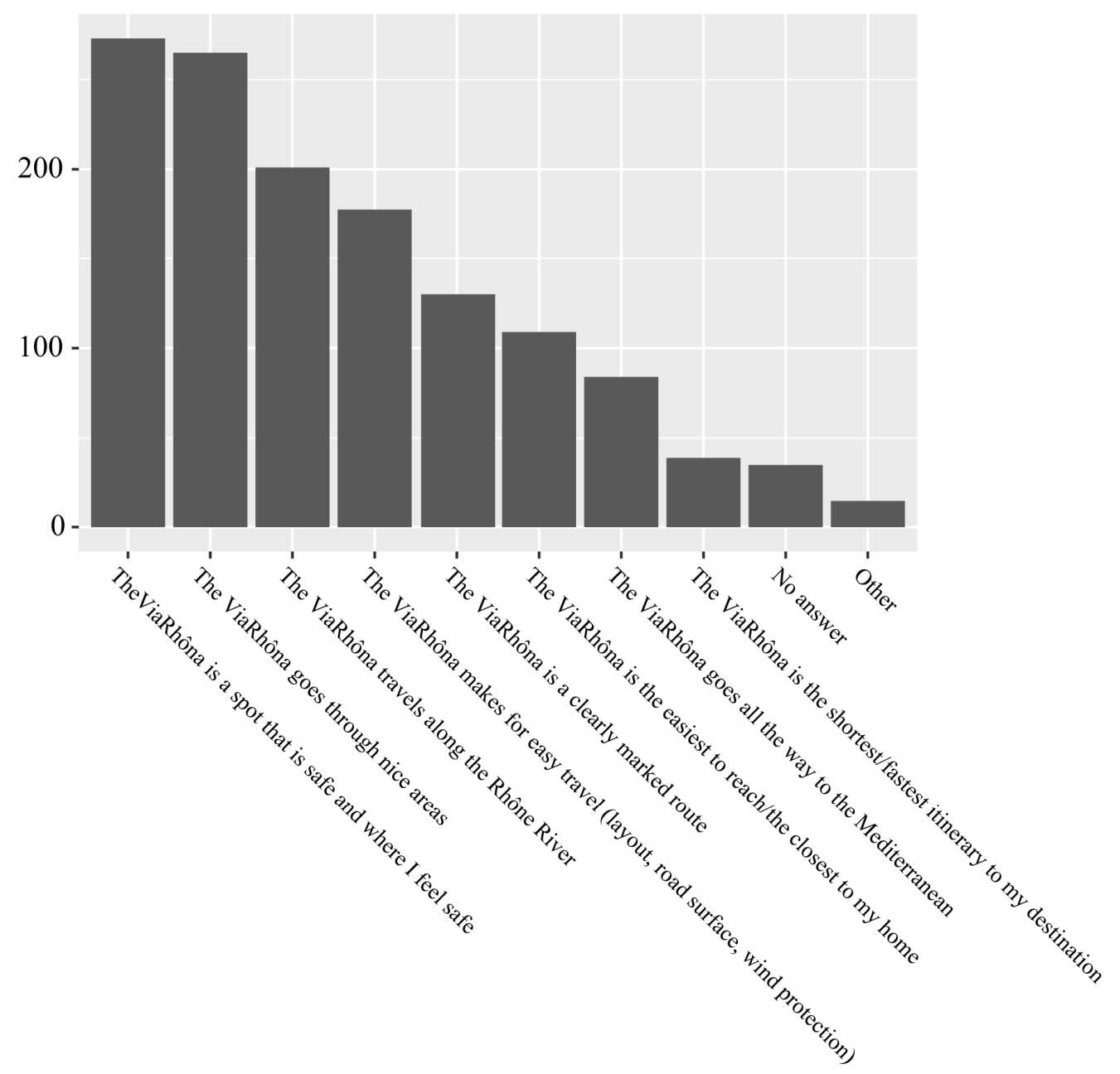

Figure 2. Breakdown of the answers to the question "For your particular activity, why did you choose the ViaRhôna rather than some other place?" (three answers maximum).

\subsubsection{More Frequent Use, New Activities}

The respondents were asked to assess the frequency of their use of the ViaRhôna and that of prior visits to the Rhône before the route existed. Excluding the 176 people who declared that they were travelling along the Rhône for the first time, 57\% of respondents who had previously spent time on the banks of the river declared that they now came more often, $40 \%$ just as often, and $3 \%$ less often. The cycle route has thus generated enhanced use of the river by both itinerant cyclists and local people who can now more easily spend time on its banks. A full $71.9 \%$ of the itinerant cyclists in the sample had never visited the Rhône before the creation of the ViaRhôna, which may signify that the cycle route is an efficient means to attract this type of user and to provide them access to the river. These conclusions are valid to a lesser degree for all types of use because, in each case, almost $30 \%$ of the questioned users discovered the banks of the Rhône thanks to the ViaRhôna. 
What can explain the fact that $3 \%$ of respondents declared that they come less frequently to the river since the creation of the ViaRhôna? These 12 people were regular visitors to the Rhône (daily (2), weekly (5), or monthly (5)) and consequently had a relatively high "potential" for a decrease in visits. Among them, 10 were over 50 years old $(p \leq 0.05)$. This decrease in frequency may be linked to the living conditions of each person (ageing, failing health, moves, changes in schedules, etc.) or to discontent with the cycle route itself and the changes incurred on the banks of the river and in the number of visitors. For example, the interviews revealed that the increasing number of people on the banks was seen negatively by some "regular visitors" who perceived the ViaRhôna as a source of disturbances (other visitors, noise, etc.) and who felt deprived of areas that they had previously enjoyed relatively exclusively. That is particularly the case for certain anglers (a typical case of conflict between recreational uses) or simply for local people in areas where tourism was previously not common. For example, that is the case of Marie-Anne, who lives in a house along the ViaRhôna in the Bugey region, immediately near the Rhône. She did not hide her hostility to the cycle route. She described the increased numbers of people and the fact that anglers and hunters had abandoned the area. She now goes to the other bank of the river for hikes or walks with her dog, thus avoiding the bank where she lives and where the ViaRhôna lies.

\subsubsection{A Modified Perceived Image of the River}

The increased number of visits contributed to modifying people's image of the Rhône. Respondents were asked to score, on a scale ranging from "not at all" (0) to "completely" (10), the degree to which their "experience along the ViaRhôna modified [their] perception of the Rhône River". The average value of the responses was 5.4 out of 10 . That indicates a real, but moderate change. We asked the people who felt their perception had been modified to present the reasons for the change. A total of 300 people responded (using 2849 words). The most frequently mentioned terms were "nature", "river", "natural", and "landscape", followed by "discover", "discovery", and "know" (see Figure 3). The discoveries made by the respondents thanks to the ViaRhôna concern primarily the landscapes and the naturalness of the Rhône. The absence of terms specific to the different categories of users would indicate that these discoveries are experiences shared by all users.

The interviewed persons also noted a change in their image of the Rhône in that they now see it as more natural than before.

For example,

"Yes, I found that there was much more... There was more nature, more real countryside than I imagined after having travelled on the highway so many times." (Pierre, 53, Swiss, itinerant cyclist and sports cyclist)

It is, however, not possible to conclude that the image of the Rhône has undergone a complete change. The interviews showed that the man-made features of the river are still an integral part of its identity and of the image held by people, even if the diversity of the different sections is also a major element.

"Interviewer: What constitutes the identity or the specificity of these different Rhône landscapes?

Interviewee: In this section, it is the use made of the river and of its force. The hydroelectric installations, the nuclear plants are not the same, but they do use the water to cool the reactors. It is the use made of the river." (Emmanuelle, 42, French from the region, itinerant cyclist)

In addition to the natural image of the river, the analysis of the interviews revealed a common trait among the interviewees, namely they think they discovered the diversity of Rhône landscapes thanks to the ViaRhôna and they see that diversity as a remarkable feature of the river. This change in the perceived image may be due to the specific conditions created by the ViaRhôna in people's experience along the river. 
"You can take the time, you have the time to really experience where you are, time that you do not necessarily have in a car. In one hour in a car, you can travel $100 \mathrm{~km}$, but that is not the case on a bicycle. You have the time to take in the ambience, the noises, the landscapes." (Élise, 30, French, itinerant cyclist)

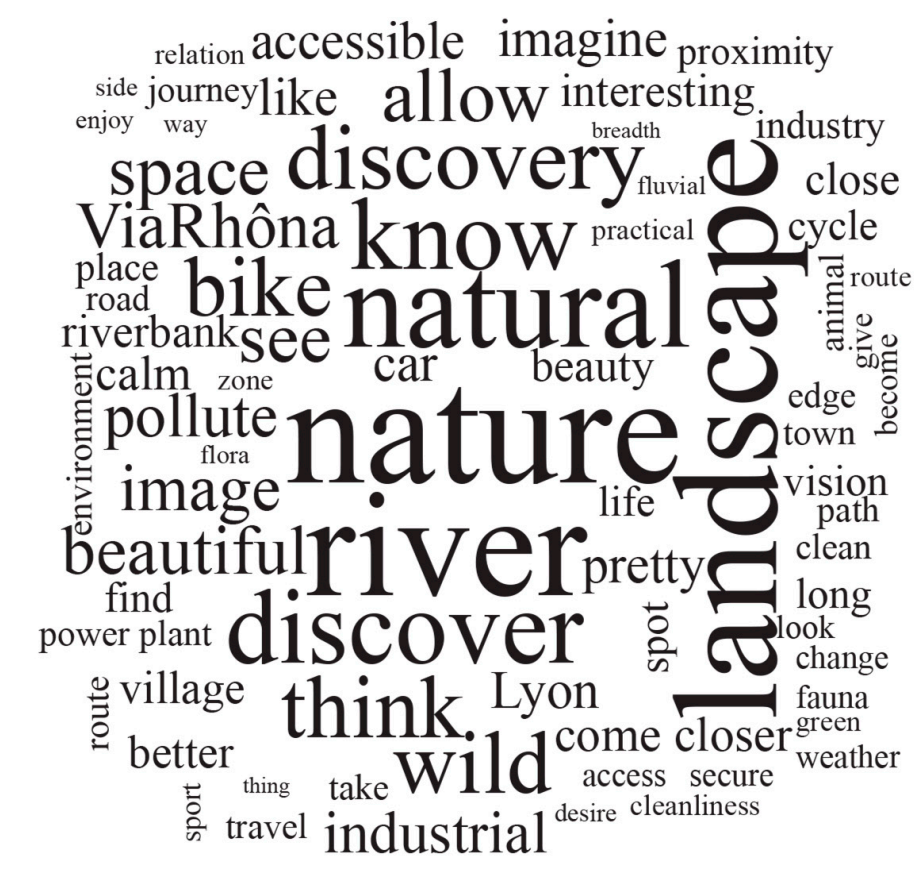

\section{Would you say that your experience along the ViaRhôna modified your perception of the Rhône River? \\ If yes, what aspects were modified? \\ Word cloud realised with IramuteQ}

Figure 3. The word cloud of responses to the question "Would you say that your experience along the ViaRhôna modified your perception of the Rhône River? If yes, what aspects were modified?".

\subsubsection{Greater Value}

The value attributed to the river by people increases thanks to the ViaRhôna. When selecting three reasons why they "attribute value to the Rhône", the respondents frequently choose aspects linked to the environment and to nature, e.g., because "the landscapes, views, sounds and odours are agreeable" (59\%), "it maintains natural areas" (38\%), and "it is home to a wide variety of plants and wild animals" (28\%). The natural environment is in competition with "recreational activities" (34\%), but it far outweighs economic and spiritual considerations, highlighting the importance of the natural environment in the minds of ViaRhôna users. The analysis showed that the value attributed to the Rhône following a trip along the ViaRhôna (measured using an analogue visual scale ranging from "less important" (0) to "more important" (10)), rose to an average score of 6.9, with 57\% of scores higher than 5. Random-forest calculations revealed that the predictors having the greatest influence on the change in value are the modification in the image of the river and the attributed value itself (see Figure 4). The modification in the image of the river leads to a modification in the attributed value, i.e., the change in the first induces an increase in the second. People who attribute a high value to the Rhône also think that value is enhanced by the ViaRhôna. 


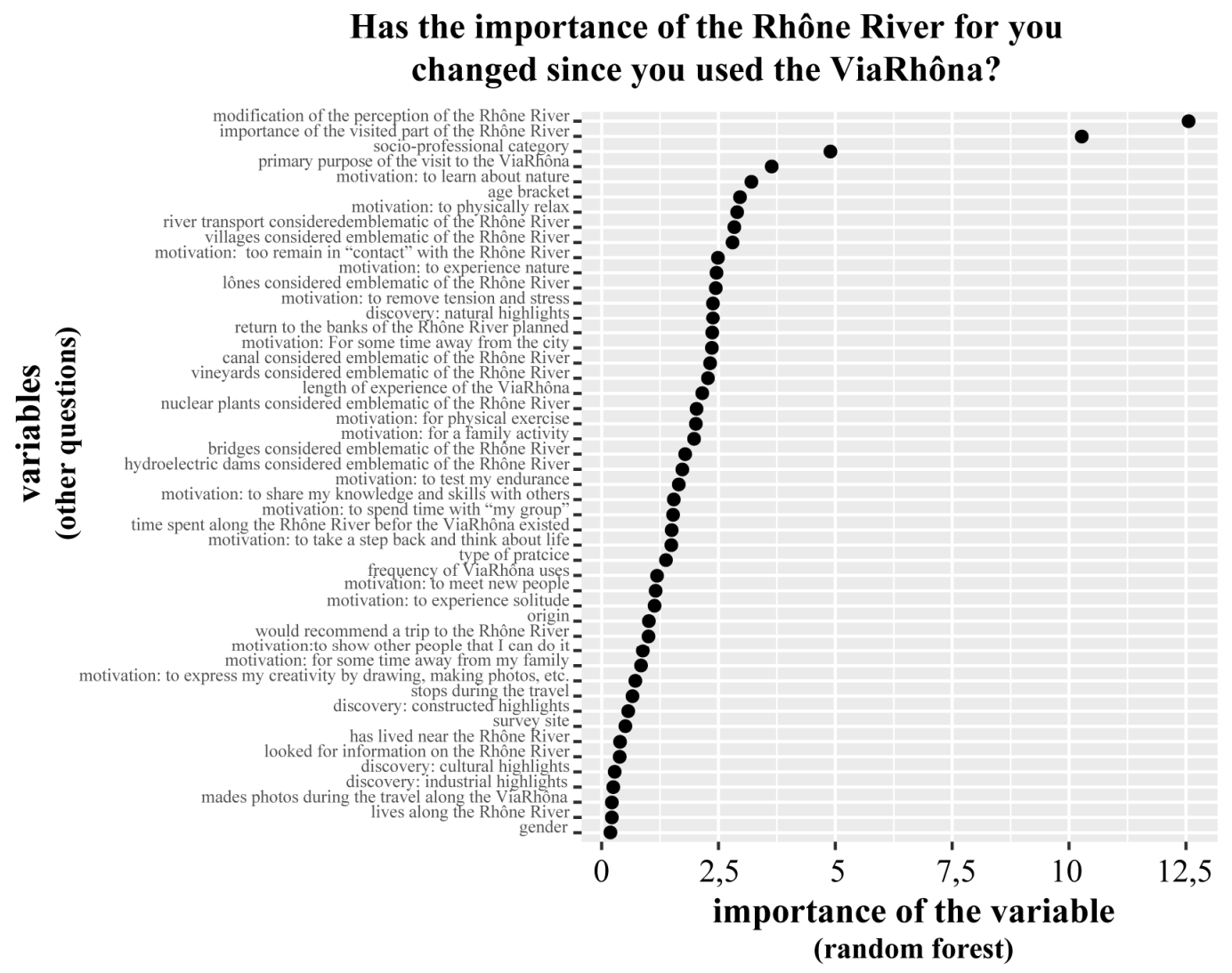

Figure 4. Relative importance of descriptors collected in the survey (as measured through the Gini score i.e., mean decrease in impurity due to each descriptor) to model the answer to the question "Has the importance of the Rhône River for you changed since you used the ViaRhôna". The higher the descriptor on the $\mathrm{Y}$ axis, the more important.

\subsubsection{Only Slight Changes in Knowledge of the River}

Though the image of the Rhône and the values attributed by the general public have changed, can the same be said for the knowledge of landscapes deemed emblematic by ViaRhôna stakeholders (developers, people in the water field)? The results of the photo-questionnaire are clear, particularly concerning former channels (locally called "lônes"), a particularly emblematic environment along the Rhône. These are channels that have been cut off from the Rhône and are supplied with water from the water table or during floods. Since the 1990s, they have been and remain the targets of ambitious restoration projects. Former channels are elements of the natural heritage of the Rhône on which the ViaRhona stakeholders place particularly high value. Given the average assessment of 5.5 out of 10, they are seen by respondents as relatively representative of the Rhône. However, former channels received one of the lowest scores among the proposed features of the Rhône, far behind the channelised Rhône (7.2), bridges (7.5), and the vineyards (7.3). What is more, respondents had difficulties in identifying and naming former channels. Only 70\% of respondents answered the question "In your opinion, what do the two photos represent?" and, among them, only $27 \%$ (i.e., 19\% of the total) used the French term "lône" or "former channel". People living along the Rhône see former channels as more emblematic of the river than people living farther from the river (average assessment 5.8 compared to 5.1) and the use of the precise French term is specific to them (specificity index 9.4). Consequently, though the ViaRhôna facilitates access to the Rhône by different types of people and modifies its image and enhances its value in their eyes, the cycle route has limited impact on enhancing knowledge of the river. The fact that "former channel" is a term specific to the mid-section (index 3), i.e., where the Île-du-Beurre nature observatory is located, an information and observation centre where people 
can learn about the natural environments of the river, would indicate that this type of centre is effective in transmitting knowledge.

\section{Discussion}

\subsection{The ViaRhôn, a Project that Modifies the Perceived Images and Values of the River}

The results show that people's experience on the ViaRhôna creates greater familiarity with the river and induces a change in its image that is highly prevalent among the various categories of users, whether those categories concern sociological or geographic aspects or the activities undertaken. Visitors to the ViaRhôna discover a river that is more diverse and natural, less consistently industrial and developed than they initially imagined. Travel along the cycle route generates a shared experience that modifies perceptions and the values attributed to the river. The easier access to the Rhône provided by the ViaRhôna and the possibility to travel at moderate speeds, i.e., speeds enabling people to truly observe the landscape, both play a role in these changes. The ViaRhôna, in direct contact with the Rhône, thus creates a possibility for a large and diversified public to access nature. By contributing to developing and diversifying mobility and recreational possibilities, it effectively provides access to Rhône landscapes that are often unknown to the people on the cycle route. For this reason, the project has resulted in significant new opportunities for people, whether they are local day trippers or foreign itinerant cyclists on the route.

The gamble by the developers and river stakeholders (in this case, the participants in the Rhône Plan) has therefore been a success. The hypothesis that greater "social connectivity" with the river [32] results in recreating bonds has been demonstrated. It is clear that the ViaRhôna creates greater affinity with the landscapes. It is possible to hypothesise that this greater affinity is likely to increase support for policies to preserve nature [2,3]. However, what nature is at issue here [33]? When they speak about rediscovering the natural Rhône, respondents are referring to a highly aesthetic nature that has little to do with the actual functioning of the environment, including the dynamic processes of ecosystems. Emblematic environments of the Rhône such as former channels are not well known and the fauna and flora are only rarely and partially mentioned by respondents. Though progress has been made in providing users with a more complex image of the river than they initially imagined, the aspects concerning the ecological functioning of the river remain absent. This deeper form of knowledge will require other transmission channels in addition to the existing. For example, the existence of an environmental training centre along the Rhône in one of the study sections (the Île-du-Beurre centre) would seem to have enhanced the knowledge of some respondents encountered during the survey.

\subsection{Users "Selected" by the Project}

The minimal variations in motivations and values noted in the three study sectors are similar to the results obtained by other studies using the same psychometric scale of values applied to other large areas, nature parks [24], and forests [34]. However, contrary to these other studies that noted significant differences in the motivations and values of residents (people living along or near the river in our study) on the one hand and visitors (people from other areas and foreigners in our study) on the other, the results here indicate general similarity between user categories, whether those categories concern sociological characteristics (age, gender, revenue level), geographic aspects (local, French, foreign), or their activities on the route (day trippers, sport cyclists, itinerant cyclists). The homogeneity of opinions on the river may result in part from the experience of the people on the ViaRhôna, however other mechanisms are likely involved. In particular, it seems that the cycle route itself plays a major role in "selecting" its users in that its characteristics enable and elicit a certain type of activity. This is particularly the case when looking at the motivations to use the ViaRhôna, which concern primarily the safety and the comfort of the cycle route. In addition to offering access to nature, the ViaRhôna provides an approach to activities integrating both safety and comfort. This double offering, combining a safe and comfortable cycle route, on the one hand, and a means to discover 
the areas travelled on the other, sums up the two main features of the ViaRhôna and explains its attractiveness. This interpretation is in line with the findings of Smith and Moore [22], for whom the affective and emotional ties of people with recreational sites and their desires in terms of recreational activities have significant influence not only on their demand for activities, but also on the degree to which they are attracted to a place and/or to a structure such as the ViaRhôna. The perception of the place (the Rhône River in this case) acts as a strong attractive force that pulls in users [34,35]. This attractiveness results in selection of users by the infrastructure. The people who travel along the ViaRhôna are motivated by similar tastes and it is their "motivation profile" that is the common characteristic among them. Conversely, their experience as users is likely to be influenced by their tastes. This link between activities and tastes is in line with standard observations of sociological research on cultural practices [36,37]. Having shared tastes, these users are likely to express similar opinions on their perception of the river and the values attributed, even if they have fairly different activities (itinerant cyclists, day trippers, etc.). This moulding of users' expectations by an infrastructure is in line with a central component of the social practice theory [17], which has established that users are selected by activities.

\subsection{The Limits to Attractiveness}

The new attractiveness of the Rhône, visible in the results of this study, may, however, encounter certain limits. In particular, the higher number of visitors may bother certain people living along the river who had for years frequented the banks of the Rhône, but are not interested in using the ViaRhôna. These negative impressions were expressed by certain persons early in the study during the exploratory interviews. The new attractiveness of the Rhone banks for certain segments of the public, due to the ViaRhôna, may lead to the exclusion of other segments. This risk is all the greater given that the cycle route was only recently finished. The number of visitors should increase massively in the months and years to come given the launch of promotional efforts for the ViaRhôna (publicity campaign, publication of the popular Guide du Routard tourist guide in February 2019, etc.). This spring (2019), there were already signs of excessive tourism (press articles mentioned trains jammed with bicycles along key parts of the route). Compared to the results presented here, it is probable that the numbers of tourists and itinerant cyclists will increase, particularly during the summer, and that the resulting problems will only worsen. It follows that the new attractiveness, though it will produce considerable tourism revenues and clearly constitutes an important factor for local development, may also deprive people living along the river of an area that they often used and appreciated. This may result in usage conflicts along the river that are much more severe than those observed today and comparable, at least in their general configuration, to the competition between tourists and local people observed in certain large cities [38,39], in protected natural areas [40], and along coasts [41]. Just as development work and tourism infrastructure reduce, on a seasonal basis or year round, the right to the city of some residents in certain particularly attractive cities [42] and disrupt the fragile equilibria of spatial justice [43], the cycle route may well have negative effects on the access rights and the use of environmental amenities of people living along the river.

\section{Conclusions}

This study throws new light on the issues of territorial development by looking at how a cycle route can create or recreate links with the surrounding landscapes. It fills a gap in the existing international literature. It is based on a case study of the ViaRhôna, a cycle route along the Rhône, an extensively developed river in France, particularly for hydroelectric power. The ViaRhôna route constitutes a physical and long-term modification of the areas where it passes. This study reveals that it also transforms the relationships between users of the cycle route and the surrounding landscapes. The ViaRhôna offers to users (walkers, cyclists, people living along the river and tourists, day trippers and sports cyclists, etc.) new and/or renewed access to the river. The analysis here confirms that this has led to an increase of activity on the riverbanks on the part of both tourists and local people. 
New activities have emerged and pre-existing activities have been reinforced. This study suggests that the features of the ViaRhôna route and the activities that it makes possible drain a special segment of the population that, in spite of its diverse sociological composition, shares similar tastes. Finally, even if the growing success of the cycle route portends the emergence of conflicts and the potential degradation of usage conditions, its creation has also resulted in an increase in the value that users attribute to the river. By enabling people to approach the Rhône, the cycle route has reinforced the social connectivity of the river and modified the image held by users. They discover a river that is more diverse and natural, less consistently industrial and developed than they initially imagined.

It follows that a cycle route and its itinerary are not a neutral element in the landscape and they have a visible effect on the relationship between a territory, the river, and society. In terms of the management of natural areas, these results raise the question as to the degree to which the rediscovery by users of the river's natural environments and the increase in the attributed value can enhance their support for policies intended to preserve the river. Travel along the ViaRhôna creates a specific set of conditions for the discovery of environments and contributes to producing superficial knowledge that clearly differs from that of an expert on rivers. Our results show that the ViaRhôna has not yet developed in users new knowledge on the natural environments of the Rhône, at least not in the sense understood by water professionals. That knowledge is, however, indispensable for any real understanding of a complex situation with conflicting issues. The participation of users, at least local users, in debates concerning development projects impacting the river highlights the need to imagine other transmission channels for knowledge in addition to a simple recreational itinerary. It also highlights the need to create centres of dialogue where the different forms of knowledge, lay and expert, can interact.

Author Contributions: Conceptualization, M.A., M.C. and S.M.; methodology, M.A., M.C., S.M., L.V. and A.R.-H.; software, L.V.; validation, M.A., M.C. and S.M.; formal analysis, M.A.; investigation, M.A. and L.C.; data curation, M.A. and L.C.; writing—original draft preparation, M.A. and M.C.; writing—review and editing, M.A., M.C., S.-M., L.V. and A.R.-H.; visualization, M.A. and L.V.; supervision, M.C.; project administration, M.C.; funding acquisition, M.C. and S.M. All authors have read and agreed to the published version of the manuscript.

Funding: The APC was funded by the Agence de l'eau Rhône Méditerranée Corse, by Electricite de France (EDF) and by the National Fund for Territorial Planning and Development (Fonds National d'Aménagement et de Développement du Territoire; FNADT), within the Plan Rhône 2015-2020 interregional project contract.

Conflicts of Interest: The authors declare no conflict of interest.

\section{References}

1. Purcell, A.T.; Lamb, R.J.; Mainardi, P.E.; Falchero, S. Preference or preferences for landscape? J. Environ. Psychol. 1994, 14, 195-209. [CrossRef]

2. Gobster, P.H.; Nassauer, J.I.; Daniel, T.C.; Fry, G. The shared landscape: What does aesthetics have to do with ecology? Landsc. Ecol. 2007, 22, 959-972. [CrossRef]

3. Nassauer, J.I. The appearance of ecological systems as a matter of policy. Landsc. Ecol. 1992, 6, $239-250$. [CrossRef]

4. Desfor, G.; Laidley, J.; Stevens, Q.; Schubert, D. (Eds.) Transforming Urban Waterfronts: Fixity and Flow; Routledge: London, UK, 2013.

5. Norcliffe, G.; Bassett, K.; Hoare, T. The emergence of postmodernism on the urban waterfront: Geographical perspectives on changing relationships. J Transp. Geogr. 1996, 4, 123-134. [CrossRef]

6. Wrenn, D.M.; Casazza, J.; Smart, E. Urban Waterfront Development; Urban Land Institute: Washington, DC, USA, 1983.

7. Baron-Yellès, N. Recréer la Nature: Écologie, Paysage et Société au Marais d'Orx; Presses de l'École Normale Supérieure: Paris, France, 2000.

8. Lefebvre, S.; Trudeau, M. La Route verte, un circuit touristique? Téoros Rev. Rech. Tour 2003, 22, 46-51.

9. Lumsdon, L.; Downward, P.; Cope, A. Monitoring of cycle tourism on long distance trails: The North Sea Cycle Route. J. Transp. Geogr. 2004, 12, 13-22. [CrossRef]

10. Meschik, M. Sustainable Cycle Tourism along the Danube Cycle Route in Austria. Tour. Plan. Dev. 2012, 9, 41-56. [CrossRef] 
11. Davodeau, H.; Pordoy, C.; Montembault, D.; Barraud, R.; Carcaud, N. Patrimonialiser la nature et les paysages: Contradictions et paradoxes au sujet des épis de la Loire armoricaine. Espace Geogr. 2013, 42, 241-253. [CrossRef]

12. Giovannini, A.; Malucelli, F.; Nonato, M. Cycle-tourist network design. Transp. Res. Procedia 2017, 22, 154-163. [CrossRef]

13. Deenihan, G.; Caulfield, B.; O'Dwyer, D. Measuring the success of the Great Western Greenway in Ireland. Tour. Manag. Perspect. 2013, 7, 73-82. [CrossRef]

14. Dickinson, J.E.; Robbins, D. Other People, Other Times and Special Places: A Social Representations Perspective of Cycling in a Tourism Destination. Tour. Hosp. Plan. Dev. 2009, 6, 69-85. [CrossRef]

15. Downward, P.; Lumsdon, L.; Weston, R. Visitor Expenditure: The Case of Cycle Recreation and Tourism. J. Sport Tour. 2009, 14, 25-42. [CrossRef]

16. Reckwitz, A. Toward a Theory of Social Practices: A Development in Culturalist Theorizing. Eur. J. Soc Theory 2002, 5, 243-263. [CrossRef]

17. Shove, E.; Pantzar, M.; Watson, M. The Dynamics of Social Practice: Everyday Life and How it Changes; Sage: London, UK, 2012.

18. Serrão, A.V.; Reker, M. Philosophy of Landscape: Think, Walk, Act; Centre for Philosophy at the University of Lisbon: Lisbon, Portugal, 2019.

19. Cottet, M. Caractériser les Valeurs Environnementales au Cours du Temps: Une étape Indispensable à la Gestion des Patrimoines Naturels: Le cas de la Restauration des Bras Morts de l'Ain et du Rhône. Available online: http://journals.openedition.org/vertigo/13558 (accessed on 27 September 2019).

20. Peyrard, O.; Prost, B. Le difficile éveil du Rhône à la civilisation des loisirs / The difficult Awakening of the Rhône to a leisure society. Géocarrefour 1997, 72, 57-65. [CrossRef]

21. Béthemont, J.; Bravard, J.P. Pour Saluer le Rhône; Libel: Paris, France, 2016.

22. Smith, J.W.; Moore, R.L. Social-Psychological Factors Influencing Recreation Demand: Evidence From Two Recreational Rivers. Environ. Behav. 2012, 45, 821-850. [CrossRef]

23. Le Lay, Y.F.; Cottet, M.; Piégay, H.; Rivière-Honegger, A. Ground Imagery and Environmental Perception: Using Photo-questionnaires to Evaluate River Management Strategies; Carbonneau, P., Piégay, H., Eds.; John Wiley and Sons: Hoboken, NJ, USA, 2012; pp. 405-426.

24. Brown, G.; Raymond, C. The relationship between place attachment and landscape values: Toward mapping place attachment. Appl. Geogr. 2007, 27, 89-111. [CrossRef]

25. Paillé, P.; Mucchielli, A. L'analyse Qualitative en Sciences Humaines et Sociales; Armand Colin: Malakoff, France, 2019.

26. Liaw, A.; Wiener, M. Classification and Regression by random Forest. R News 2002, 2, 18-22.

27. Lebart, L.; Salem, A. Statistique Textuelle; Dunod: Paris, France, 1994.

28. Ratinaud, P. Iramuteq: Interface de R pour les Analyses Multidimensionnelles de Textes et de Questionnaires. Available online: http://www.iramuteq.org/documentation/fichiers/Pas\%20a\%20Pas\%20IRAMUTEQ_0. 7alpha2.pdf (accessed on 13 April 2017).

29. Crossely, S.; Salsbury, T.; McNamara, D. Validating Lexical Measures Using Human Scores of Lexical Proficiency; Jarvis, S., Daller, M., Eds.; John Benjamins Publishing Company: Amsterdam, The Netherlands, 2003.

30. Garnier, B.; Guérin-Pace, F. Appliquer les Méthodes de la Statistique Textuelle; CePeD: Paris, France, 2010.

31. Mercat, N. Étude de Fréquentation et d'impact Economique de la ViaRhôna en 2017. Rapport Final; Indigo-Symetris: Région Provence-Alpes-Côte d'Azur, France, 2018.

32. Kondolf, G.M.; Pinto, P.J. The social connectivity of urban rivers. Geomorphology 2017, 277, 182-196. [CrossRef]

33. Gobster, P.H. Visions of nature: Conflict and compatibility in urban park restoration. Landsc. Urban Plan. 2001, 56, 35-51. [CrossRef]

34. Williams, D.; Vaske, J. The Measurement of Place Attachment: Validity and Generalizability of a Psychometric Approach. For. Sci. 2003, 49, 830-840.

35. Hailu, G.; Boxall, P.C.; McFarlane, B.L. The influence of place attachment on recreation demand. J. Econ. Psychol. 2005, 26, 581-598. [CrossRef]

36. Fleury, L.; Clark, T.N. Sociology of Culture and Cultural Practices: The Transformative Power of Institutions; Lexington Books: Lanham, MD, USA, 2014.

37. Swartz, D. Culture E Power: The Sociology of Pierre Bourdieu; Chicago Press: Chicago, IL, USA, 2003. 
38. Nofre, J.; Giordano, E.; Eldridge, A.; Martins, J.C.; Sequera, J. Tourism, nightlife and planning: Challenges and opportunities for community liveability in La Barceloneta. Tour. Geogr. 2018, 20, 377-396. [CrossRef]

39. Novy, J.; Colomb, C. Urban tourism and its discontents. An introduction. In Protest Resist Tour City; Colomb, C., Novy, J., Eds.; Routledge: New York, NY, USA, 2016; pp. 1-30.

40. Depraz, S.; Laslaz, L. Conflicts, Acceptance Problems and Participative Policies in the National Parks of the French Alps. Eco.Mont. J. Prot. Mt. Areas Res. Manag. 2017, 9, 46-56. [CrossRef]

41. Cadoret, A. L'attachement aux lieux dans les conflits liés à l'environnement sur le littoral: Une ressource pour leur régulation. Place attachment in environmental conflicts on coastal zone: A resource for their resolution. VertigO 2017, 17. Available online: http://journals.openedition.org/vertigo/18436 (accessed on 27 September 2019). [CrossRef]

42. Perkumienè, D.; Pranskūnienè, R. Overtourism: Between the Right to Travel and Residents' Rights. Sustainability 2019, 11, 2138. [CrossRef]

43. Soja, E.W. Seeking Spatial Justice; Univ. of Minnesota Press: Minneapolis, MN, USA, 2010.

Publisher's Note: MDPI stays neutral with regard to jurisdictional claims in published maps and institutional affiliations.

(C) 2020 by the authors. Licensee MDPI, Basel, Switzerland. This article is an open access article distributed under the terms and conditions of the Creative Commons Attribution (CC BY) license (http://creativecommons.org/licenses/by/4.0/). 